Prof. Corneliu-Liviu POPESCU

\title{
Notificarea internațională a măsurilor derogatorii privind drepturile omului
}

\author{
International notification of derogations on human rights
}

\section{Cuvinte cheie}

Drepturile omului. Situații excepționale. Măsuri derogatorii. Pactul internațional relativ la drepturile civile și politice. Convenția europeană a drepturilor omului. Notificarea Secretarului General al ONU. Notificarea Secretarului General al Consiliului Europei.

\section{Key words}

Human rights. Exceptional situations. Derogations. International Covenant on Civil and Political Rights. European Convention on Human Rights. Notification of the Secretary General of the UN. Notification of the Secretary General of the Council of Europe.

\section{Rezumat}

În situații excepționale, sunt permise și necesare măsuri derogatorii privind drepturile omului. $O$ condiție de validitate a măsurilor derogatorii, din perspectiva Pactului internațional relativ la drepturile civile și politice și a Convenției europene a drepturilor omului, este notificarea Secretarului General al ONU și a Secretarului General al Consiliului Europei.

\section{Abstract}

In exceptional circumstances, derogations from human rights are permitted and necessary. A condition for the validity of derogating measures, in the light of the International Covenant on Civil and Political Rights and the European Convention on Human Rights, is represented by the notification of the Secretary General of the United Nations and of the Secretary General of 
the Council of Europe.

1. În art. 48 lit. b) din anexa nr. 1 la Decretul Președintelui României nr. 195/2020 privind instituirea stării de urgență pe teritoriul României ${ }^{1}$ se prevede că:

"Pe perioada stării de urgență, Ministerul Afacerilor Externe îndeplinește următoarele atribuții:

[...]

b) va notifica Secretarului General al ONU și Secretarului General al Consiliului Europei măsurile adoptate prin decretul de instituire a stării de urgență care au ca efect limitarea exercițiului unor drepturi și libertăți fundamentale, în conformitate cu obligațiile internaționale ce revin României;".

În mod similar, art. 73 lit. b) din anexa nr. 1 la Decretul Președintelui României nr. 240/2020 privind prelungirea stării de urgență pe teritoriul României $^{2}$ dispune că:

"Pe durata stării de urgență, Ministerul Afacerilor Externe îndeplinește următoarele atribuții:

[...]

b) va notifica Secretarului General al ONU și Secretarului General al Consiliului Europei măsurile adoptate prin decretul de prelungire a stării de urgență care au ca efect limitarea exercițiului unor drepturi și libertăți fundamentale, în conformitate cu obligațiile internaționale ce revin României;".

2. După adoptarea și publicarea primului decret, cel privind instituirea stării de urgență, au apărut (pe pagina proprie de Facebook, pe site-ul Internet propriu sau în presă) declarații publice fanteziste privind decizia statului român, în plan internațional, vizând măsurile derogatorii de la drepturile omului.

3. Astfel, un judecător, fost membru al Consiliului Superior al Magistraturii, foarte vizibil în plan mediatic, a postat pe pagina proprie de Facebook:

"Văd o știre cum că România a înștiințat Consiliul Europei [...] să deroge de la CEDO pe durata stării de urgență, invocând art. 15 din Convenția Europeană [...]. [...] Consider hazardată această solicitare a României și, ca 
judecător, sunt obligat să o denunț publicului. AȘA CEVA NU SE POATE FACE! Nu suntem în război cu oamenii sau cu vreun alt stat, ci cu un nenorocit de virus. $[\ldots]^{3}$.

Postarea a fost preluată de presă ca știre, redându-i conținutul ${ }^{4}$.

Tot presa a reluat, citând exact între ghilimele, și alte afirmații ale aceluiași judecător ${ }^{5}$ :

- "De aceea, cred că România trebuia să anunțe ONU și Consiliul Europei că e firesc ca anumite drepturi ale omului să fie afectate în timpul stării de urgență, nicidecum să notifice la modul general - cu privire la toate drepturile, cu excepția celor șase menționate mai sus - că derogă de la respectarea Convenției Europene a Drepturilor Omului în această perioadă. Invocând aplicarea art. 15 din CEDO, practic România se sustrage de la orice formă de ocrotire a drepturilor sau de răspundere ulterioară pentru încălcarea lor în timpul prezentei stări de urgență. În felul acesta, cred s-a găsit o cale nepotrivită prin care țara noastră să se sustragă de la necesitatea respectării unor angajamente internaționale."6;

- "ar putea fi organizate procese sumare, neechitabile și fără să avem judecătorii de drept", eventual de "judecători militari făcuți peste noapte", "fără să se asigure dreptul la apărare al părților"; "Intervenția armată pe stradă, în diferite scopuri, ar putea fi un alt motiv al derogării României de la articolul 15 din Convenția Europeană pentru Drepturile Omului"; "Nu vrem să stârnim îngrijorări nejustificate", dar "retragerea din tratatul CEDO, care era garanția cea mai puternică pentru respectarea drepturilor noastre, ne îngrijorează"7 .

Ca să rezumăm, în opinia domnului judecător:

- România a solicitat Consiliului Europei să deroge de la Convenția Europeană a Drepturilor Omului;

- România a notificat la modul general, cu privire la toate drepturile (cu excepția celor de nederogat), că derogă de la respectarea Convenției europene a drepturilor omului;

- România se sustrage de la orice formă de ocrotire a drepturilor omului, de la răspunderea juridică pentru încălcarea lor, de la respectarea angajamentelor sale internaționale;

- România s-a retras din Convenția europeană a drepturilor omului.

Sub aspectul formei, domnul judecător arată că se simte obligat să denunțe publicului situația, pentru că așa ceva nu se poate face, dar afirmă că nu vrea să stârnească îngrijorări nejustificate, deși în urma măsurii luate de 
statul român sunt posibile intervenția armată pe stradă și procese sumare, inechitabile și fără respectarea dreptului la apărare, judecate de judecători militari făcuți peste noapte.

4. Similar, o organizație neguvernamentală specializată în apărarea drepturilor omului a dat publicității și a postat pe site-ul Internet propriu un comunicat $^{8}$ potrivit căruia:

- "activarea art. 15 din Convenție" s-a făcut "fără a aduce la cunoștința cetățenilor" și la "cunoștința publicului de către Guvernul României" acest lucru;

- "România suspendă temporar aplicabilitatea Convenției Europene a Drepturilor Omului pe teritoriul său", cu excepția drepturilor de nederogat;

- "în România nu mai este aplicabilă Convenția, [...] drepturile prevăzute de aceasta nu ne mai sunt garantate, cu alte cuvinte ele sunt suspendate temporar";

- "gravitatea constă în faptul vă NIMENI nu a adus la cunoștința cetățenilor acest lucru, respectiv NIMENI nu a explicat de ce a făcut România acest demers și care sunt efectele pentru cetățeni";

- "Solicităm, așadar, guvernanților să ne informeze în concret cu privire la derogarea solicitată Secretariatului General al Curții Europene a Drepturilor Omului!".

În esență, în opinia acestei organizații neguvernamentale specializate în materia drepturilor omului:

- România a solicitat Secretariatului General al Curții Europene a Drepturilor Omului o derogare, adică activarea art. 15 din Convenția europeană a drepturilor omului;

- cu excepția drepturilor de nederogat, România a suspendat aplicabilitatea Convenției europene pe teritoriul său, aceasta nu mai este aplicabilă în România, drepturile convenționale nu mai sunt garantate;

- autoritățile nu au adus acest lucru la cunoștința cetățenilor, care nu știu care sunt efectele pentru ei.

5. Spre deosebire de ingerințe, care sunt limitările ordinare, din viața zilnică, ale drepturilor omului, măsurile derogatorii sunt limitări mult mai severe, care pot fi operate in situații excepționale, de criză.

Cu rare excepții, drepturile omului, care sunt drepturi individuale, nu pot 
fi absolutizate, ci pot fi limitate, fie pentru protejarea drepturilor altora, fie pentru asigurarea interesului general. Societatea democratică, singura compatibilă cu drepturile omului, este cea care asigură un just echilibru între drepturile individuale între ele, precum și între drepturile individuale și interesul general al societății.

În situații excepționale (având fie cauze sociale, fie cauze naturale), când existența și/sau funcționarea normală a societății și/sau a democrației este/sunt în pericol, statele pot recurge la măsuri derogatorii, adică la limitări mult mai ample (prin natura, intensitatea, sfera destinatarilor și întinderea teritorială) ale drepturilor omului decât în perioadele normale, pentru a salva existența și a menține buna funcționare ale societății, democrației și indivizilor și pentru a asigura revenirea la normalitate.

Recurgerea la măsuri derogatorii privind drepturile omului nu este arbitrară, nu este o stare de non-drept (a-legală) sau o stare de anti-drept (ilegală), ci, așa cum se arată în literatura de specialitate, este o stare de legalitate excepțională, care înlocuiește legalitatea ordinară. Legalitatea nu dispare însă, rămânem în cadrul statului de drept, al preeminenței dreptului.

6. Nici Convenția europeană a drepturilor omului, nici Pactul internațional relativ la drepturile civile și politice nu ignoră instituția juridică a măsurilor derogatorii privind drepturile omului.

Sediul materiei este reprezentat de art. 15 din Convenție, respectiv de art. 4 din Pact.

Un stat care este Parte la ambele tratate internaționale trebuie să respecte cumulativ condițiile figurând în aceste două tratate.

Comitetul Drepturilor Omului (gardianul Pactului) este competent să verifice exclusiv respectarea exigențelor art. 4 din Pact.

În schimb, Curtea Europeană a Drepturilor Omului (gardiana Convenției) este competentă (repetăm, în ipoteza unui stat Parte atât la Convenție, cât și la Pact) să verifice atât respectarea art. 15 din Convenție, cât și respectarea art. 4 din Pact.

Deși ca regulă Curtea are competență ratione materiae drepturile consacrate de Convenție (conform art. 19), în cazul art. 15 din Convenție, privitor la măsurile derogatorii, regăsim o excepție expresă, care extinde competența Curții. Astfel, una dintre condițiile de validitate a măsurilor derogatorii, conform art. 15 din Convenție (iar respectarea art. 15 din 
Convenție este de competența materială a Curții), este ca ele să nu fie în contradicție cu celelalte obligații ale statului Parte la Convenție decurgând din Dreptul internațional public. Or, în ipoteza noastră, fiind vorba de un stat Parte atât la Convenție, cât și la Pact, el trebuie să respecte și art. 4 din Pact, iar respectarea art. 4 din Pact este impusă de art. 15 din Convenție, verificarea respectării acestui din urmă text fiind de competența Curții. Ca o paranteză, conform art. 15 din Convenție Curtea este competentă să verifice, în caz de măsuri derogatorii, și respectarea Dreptului internațional cutumiar al drepturilor omului, precum și al oricăror alte norme internaționale aplicabile (spre exemplu, poate deveni și judecător de Drept internațional umanitar, dacă măsurile derogatorii își au originea într-o stare de conflict armat; de altfel, art. 15 para. 2 din Convenție - problemă tot de competența Curții - vorbește de "deces rezultând din acte licite de război", caracterul licit al decesului, din perspectiva art. 15 raportat la art. 2 din Convenție, fiind evident analizat de Curte din perspectiva Dreptului internațional umanitar).

7. Pentru a recurge la măsurile derogatorii privind drepturile omului, statul Parte la Convenție și la Pact nu are nevoie să ceară / să solicite, în prealabil sau ulterior, vreo "aprobare", "autorizare", "permisiune" etc., nici în sistemul onusian, nici în sistemul regional european.

Măsurile derogatorii se decid de stat, prin dreptul său intern și conform dreptului său intern, respectând în egală măsură art. 4 din Pact și art. 15 din Convenție.

8. Cum măsurile derogatorii privind drepturile omului reprezintă o instituție convențională (consacrată de cele două tratate internaționale), recurgerea la ele nu are, în niciun caz, semnificația că statul a suspendat aplicarea Convenției / a Pactului, că nu mai respectă dispozițiile Convenției / Pactului sau drepturile omului consacrate de acestea, că nu mai este Parte la Convenție / Pact sau că nu va putea răspunde juridic internațional (în fața Comitetului Drepturilor Omului sau a Curții Europene a Drepturilor Omului) pentru violarea Pactului (inclusiv a art. 4) sau a Convenției (inclusiv a art. 15).

Dimpotrivă, așa cum spuneam, dacă există o situație excepțională care să reclame măsuri derogatorii privind drepturile omului, aplicarea art. 4 din Pact și a art. 15 din Convenție este obligatorie. Tocmai neaplicarea acestor norme convenționale ar semnifica încălcarea obligațiilor internaționale 
convenționale ale statului Parte și ar atrage răspunderea juridică internațională a acestuia.

9. Recurgerea la măsurile derogatorii, făcută printr-un act de drept intern, trebuie notificată internațional, trebuie adusă la cunoștința subiectelor de Drept internațional public indicate în art. 4 din Pact, respectiv în art. 15 din Convenție.

Prin urmare, între condițiile de validitate a măsurilor derogatorii privind drepturile omului figurează și aceea de informare internațională.

Informarea privește măsurile derogatorii care au fost deja luate de stat și precizează drepturile vizate (sau - este același lucru - articolele convenționale vizate). În niciun caz informarea nu este "în alb", cu referire la toate drepturile convenționale (mai puțin cele de nederogat), deoarece limitarea nu ar corespunde criteriilor de validitate constând în nevoia socială imperioasă și în proporționalitatea strictă.

10. În concret - și ne referim exclusiv la acest aspect formal -, autoritățile române au procedat cu respectarea clară a exigențelor art. 4 din Pact și ale art. 15 din Convenție:

- au decis măsuri derogatorii privind drepturile omului (de imediată aplicare ori de aplicare ulterioară graduală, în raport cu evoluția situației), prin decretul de instituire / de prelungire a stării de urgență; acesta este deci actul prin care s-au decis măsuri derogatorii ori s-a permis ca în viitor să se decidă gradual măsuri derogatorii (prin ordonanțe militare sau prin ordine ale șefului Departamentului pentru Situații de Urgență);

- decretul de instituire / de prelungire a stării de urgență a fost publicat în Monitorul Oficial al României;

- măsurile derogatorii decise prin decretul de instituire / de prelungire a stării de urgență au fost notificate post factum Secretarului General al ONU (în temeiul art. 4 din Pact) și Secretarei Generale a Consiliului Europei ${ }^{9}$ (în temeiul art. 15 din Convenție); decretul de instituire / de prelungire a stării de urgență prevede expres acest lucru, deși nu era strict necesar, obligația decurgând direct din cele două norme convenționale, care sunt direct aplicabile în dreptul intern român cu valoare interpretativă constituțională și forță supra-legislativă, potrivit art. 11 alin. (2) și art. 20 din Constituție; nu s-a solicitat deci ceva la nivel internațional, ci doar s-a informat; 
- s-a comunicat la nivel internațional, în integralitate, decretul de instituire / de prelungire a stării de urgență $^{10}$, deci informarea a vizat drepturile omului supuse măsurilor derogatorii; nu s-a derogat astfel de la toate drepturile convenționale (cu excepția celor de nederogat), ci exclusiv de la cele pentru care chiar decretul de instituire / de prelungire a stării de urgență prevede măsuri derogatorii;

- în niciun caz nu era necesară o informare publică din partea autorităților că a fost executată obligația de informare prevăzută de art. 4 din Pact și de art. 15 din Convenție; ceea ce trebuie adus la cunoștință publică este actul prin care se decid măsurile derogatorii (decretul de instituire / de prelungire a stării de urgență), adică actul de proclamare oficială (în termenii art. 4 din Pact), pe acesta trebuie să îl respecte destinatarii, iar acest lucru s-a întâmplat; obligația de informare prevăzută de art. 4 din Pact și de art. 15 din Convenție este strict în plan internațional, iar informarea internațională nu poartă asupra vreunei alte măsuri derogatorii decât cele decise prin actul intern.

11. Informarea internațională prevăzută de art. 15 din Convenție și de art. 4 din Pact nu numai că nu semnifică suspendarea aplicării Convenției / Pactului, suspendarea obligației de respectare a drepturilor convenționale, inexistența răspunderii statului în caz de violare a drepturilor convenționale ori pierderea calității de Parte la Convenție / Pact, ci, dimpotrivă, înseamnă respectarea și executarea obligațiilor juridice internaționale, care sunt și rămân în vigoare.

Tocmai absența informării internaționale prevăzute de art. 4 din Pact sau de art. 15 din Convenție ar fi putut atrage răspunderea juridică internațională a statului și ar fi diminuat garantarea drepturilor omului.

12. Astfel, din perspectiva garantării internaționale a drepturilor omului, atât Convenția, cât și Pactul instituie un mecanism de garanție colectivă.

Convenția și Pactul nu doar consacră drepturi având ca titulari particularii, ci creează un regim juridic internațional imperativ, de ordine publică. Toate statele Părți la un tratat internațional multilateral în materia drepturilor omului sunt interesate de respectarea drepturilor omului de celelalte state Părți.

Cu referire la cazul concret al Convenției europene a drepturilor omului, 
art. 33 reglementează instituția juridică a plângerilor statale (cauzele interstatale). Pentru apărarea ordinii publice europene în materia drepturilor omului, în absența unui Minister Public european titular al unei acțiuni publice, fiecare stat Parte la Convenție a primit dreptul să sesizeze Curtea pe calea acțiunii populare. Scopul acțiunii populare (plângerea statală) nu este protejarea drepturilor statului reclamant (care, deci, nu trebuie să justifice vreun interes de a acționa) și nici măcar protejarea drepturilor resortisanților săi (în sistemul regional european particularii având acces direct la jurisdicția europeană, pe calea plângerii individuale, reglementată de art. 34 din Convenție, deci neavând nevoie de exercitarea de statul Parte de cetățenie a protecției diplomatice, ca în Dreptul internațional clasic).

Or, art. 15 para. 3 din Convenție prevede informarea, de statul Parte la Convenție care a decis să recurgă la măsuri derogatorii privind drepturile omului, a Secretarului General al Consiliului Europei. La rândul său, Rezoluția 56 (16) a Comitetului Miniștrilor al Consiliului Europei dispune că această informare trebuie comunicată în cel mai scurt timp de Secretarul General al Consiliului Europei tuturor celorlalte state Părți la Convenție.

Distinct, art. 52 din Convenție atribuie Secretarului General al Consiliului Europei o putere de anchetă, impunând statelor Părți la Convenție să răspundă cererilor acestuia și să îi furnizeze explicațiile cerute privind aplicarea Convenției.

Rezultă că, executându-și obligația de notificare prevăzută de art. 15 para. 3 din Convenție, un stat Parte nu doar că nu suspendă aplicarea Convenției sau respectarea drepturilor consacrate de aceasta, ci, dimpotrivă, asigură garantarea internațională a acestora, întrucât prin furnizarea informațiilor se naște posibilitatea utilizării mecanismelor internaționale de control (fie cel de anchetă a Secretarului General al Consiliului Europei, fie cel judiciar exercitat de Curte la sesizarea oricărui alt stat Parte la Convenție).

13. Similar, din perspectiva răspunderii juridice internaționale a statului, dacă acesta nu își execută obligația de notificare internațională impusă de art. 15 para. 3 din Convenție, i se va putea angaja răspunderea internațională.

Pe de o parte, poate fi vorba de o răspundere directă, prin împiedicarea / stânjenirea exercitării puterii de anchetă de Secretarul General al Consiliului Europei sau a dreptului de sezină inter-statală a Curții de orice alt stat Parte la Convenție. 
Pe de altă parte, în absența notificării internaționale, măsurile derogatorii nu sunt considerate valide. În consecință, în cazul unui litigiu în fața Curții, unde se invocă violarea unui drept convențional, statul pârât nu se va putea apăra valabil susținând validitatea măsurilor derogatorii (deci, absența violării), deci Curtea va verifica limitarea drepturilor omului doar din perspectiva ingerințelor (adică a limitărilor ordinare); or, este evident că limitările, fiind mult mai ample decât simplele ingerințe, nu sunt valide decât dacă ar putea fi calificate drept măsuri derogatorii (lucru însă imposibil în absența îndeplinirii condiției de validitate a existenței notificării internaționale); se va ajunge, deci, la constatarea violării Convenției prin limitări severe care nu pot fi calificate (prin amploarea lor) drept ingerințe, deci la angajarea răspunderii juridice internaționale a statului, iar nu la exonerarea lui de răspundere.

14. Ca o concluzie cu o tenta personală, dacă la un examen de anul III (la Colegiul Juridic Franco-Român) sau de anul IV (la Facultatea de Drept) un student mi-ar fi scris un asemenea răspuns la examen, ar fi luat cu siguranță nota 2 (din 20), respectiv calificativul "respins". Lucrarea lui ar fi făcut obiectul discuțiilor cu colaboratorii și asistenții mei și am fi râs (dar și plâns) împreună.

Fiind însă vorba de afirmații publice ale unor subiecte de drept care ar fi trebuit să fie avizate în domeniu (iar, în caz contrar, ar fi trebuit să tacă), ele vor fi folosite ca material didactic pentru viitoarele generații de studenți, masteranzi și doctoranzi, inclusiv pentru a stârni râsul acestora (metoda învățării ludice).

04.05.2020

Materialul a fost publicat în revista online a Facultăţii de Drept, $\underline{A U B D-}$ Forum Juridic nr. 2/2020.

\footnotetext{
${ }^{1}$ Publicat în Monitorul Oficial al României, partea I, nr. 212/16.03.2020.

2 Publicat în Monitorul Oficial al României, partea I, nr. 311/14.04.2020.

${ }^{3}$ https://www.facebook.com/cristi.danilet/posts/3650130258362426, postare din 19.03.2020, accesată ultima dată pe 04.05.2020, prin intermediul link-ului conținut în I.S., Romania activează derogarea de la Convenția Drepturilor Omului. Judecător: Consider hazardată aceasta solicitare!, publicat în ziare.com pe 20.03.2020, accesat ultima dată pe 04.05.2020,
} 
la adresa electronică: http://www.ziare.com/stiri/cedo/romania-activeaza-derogarea-de-laconventia-drepturilor-omului-judecator-consider-hazardata-aceasta-solicitare-1602585.

${ }^{4}$ E.g.: I.S., Romania activează derogarea [...], supracit.; I.H., Judecătorul Dănileț: Prin derogarea de la aplicarea CEDO, România se sustrage de la orice formă de ocrotire a drepturilor sau de răspundere ulterioară pentru încălcarea lor, publicat în hotnews.ro pe 22.03.2020, accesat ultima data pe 04.05.2020, la adresa electronică: https://www.hotnews.ro/stiri-esential-23742330-judecatorul-danilet-prin-derogarea-aplicaraeacedo-romania-sustrage-orice-forma-ocrotire-drepturilor-sau-raspundere-ulterioara-pentruincalcarea-lor.htm.

${ }^{5} \mathrm{Nu}$ avem știință de vreo replică publică a domnului judecător, în care să susțină că afirmațiile sale nu există ori nu au fost redate exact.

${ }^{6}$ I.H., Judecătorul Dănileț: Prin derogarea [...], supracit.

${ }^{7}$ Sabina Fati, România suspendă drepturile omului: urmează scenarii dure? Activarea art. 15 din CEDO, publicat în romania.europalibera.org pe 20.03.2020, accesat ultima dată pe 04.05.2020, la adresa electronică: https://romania.europalibera.org/a/românia-suspendădrepturile-omului-urmează-scenarii-dure-activarea-art-15-din-cedo-/30500019.html.

${ }^{8}$ Centrul de Resurse Juridice, România suspendă temporar, prin derogare, aplicabilitatea Convenției Europene a Drepturilor Omului fără să-și anunțe cetățenii!, publicat pe site-ul crj.ro pe 20.03.2020, accesat ultima dată pe 04.05.2020, la adresa electronică: http://www.crj.ro/romania-suspenda-temporar-prin-derogare-aplicabilitatea-conventieieuropene-a-drepturilor-omului-fara-sa-si-anunte-cetatenii/.

${ }^{9}$ Comunicatul Centrului de Resurse Juridice face vorbire, incorect, de Secretariatul General al Curții Europene a Drepturilor Omului, în realitate fiind vorba de Secretarul General al Consiliului Europei, Curtea dispunând de Grefă.

${ }^{10}$ S-au notificat: decretul de instituire a stării de urgență; o rectificare (absența contrasemnării din partea Primului-Ministru al Guvernului); decretul de prelungire a stării de urgență. În plus, s-au făcut informări distincte privind măsurile derogatorii decise prin ordonanțe militare (dar nu și prin ordine ale șefului Departamentului pentru Situații de Urgență) și ordonanțe de urgență. A se vedea site-ul oficial al Consiliului Europei - Biroul tratatelor, accesat ultima dată pe 04.05.2020, la adresa electronică: https://www.coe.int/fr/web/conventions/full-list//conventions/webContent/62111354. 